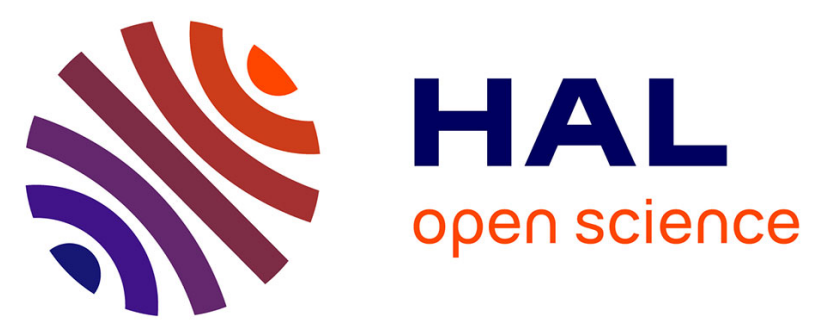

\title{
Applying new tools to cephalopod trophic dynamics and ecology: perspectives from the Southern Ocean Cephalopod Workshop, February 2-3, 2006
}

\author{
George D Jackson, Paco Bustamante, Yves Cherel, Elizabeth A Fulton, Eric
}

P.M Grist, Christine H Jackson, Peter D Nichols, Heidi Pethybridge, K

Phillips, R D Ward, et al.

\section{To cite this version:}

George D Jackson, Paco Bustamante, Yves Cherel, Elizabeth A Fulton, Eric P.M Grist, et al.. Applying new tools to cephalopod trophic dynamics and ecology: perspectives from the Southern Ocean Cephalopod Workshop, February 2-3, 2006. Reviews in Fish Biology and Fisheries, 2006, 17, pp.79-99. hal-01228921

\section{HAL Id: hal-01228921 \\ https://hal.science/hal-01228921}

Submitted on 15 Nov 2015

HAL is a multi-disciplinary open access archive for the deposit and dissemination of scientific research documents, whether they are published or not. The documents may come from teaching and research institutions in France or abroad, or from public or private research centers.
L'archive ouverte pluridisciplinaire HAL, est destinée au dépôt et à la diffusion de documents scientifiques de niveau recherche, publiés ou non, émanant des établissements d'enseignement et de recherche français ou étrangers, des laboratoires publics ou privés. 
Applying new tools to cephalopod trophic dynamics and ecology: perspectives from the Southern Ocean Cephalopod Workshop, February 2-3, 2006

Jackson $\mathrm{GD}^{1 *}$, Bustamante $\mathrm{P}^{2}$, Cherel $\mathrm{Y}^{3}$, Fulton $\mathrm{EA}^{4}$, Grist $\mathrm{EPM}^{4}$, Jackson $\mathrm{CH}^{1}$, Nichols $\mathrm{PD}^{4,5}$, Pethybridge $\mathrm{H}^{1}$, Phillips $\mathrm{K}^{1}$, Ward $\mathrm{RD}^{4}$, Xavier $\mathrm{JC}^{6,7}$

${ }^{1}$ Institute of Antarctic and Southern Oceanic studies, University of Tasmania, Private Bag 77, Hobart, TAS 7001, Australia

${ }^{2}$ Centre de Recherche sur les Ecosystèmes Littoraux Anthropisés, UMR 6217 CNRSIFREMER, Université de La Rochelle, 22 Avenue Michel Crépeau, 17042 La Rochelle Cedex, France

${ }^{3}$ Centre d'Etudes Biologiques de Chizé, UPR 1934 du CNRS, BP 14, 79360 Villiers-en-Bois, France

${ }^{4}$ CSIRO Marine and Atmospheric Research, GPO Box 1538, Hobart, TAS 7001, Australia

${ }^{5}$ Antarctic and Climate Ecosystems CRC, GPO Box 252-80, Hobart, TAS 7001, Australia

${ }^{6}$ British Antarctic Survey, High Cross, Madingley Road, CB3 OET Cambridge, UK

${ }^{7}$ Centre of Marine Sciences University of Algarve, Campus of Gambelas, 8000-139 Faro, Portugal

*Corresponding author

e-mail: george.jackson@utas.edu.au 
Abstract: A two day workshop on Southern Ocean cephalopods was held in Hobart, Tasmania, Australia prior to the triennial 2006 Cephalopod International Advisory Council (CIAC) symposium. The workshop provided a second international forum to present the current state of research and new directions since the last Southern Ocean cephalopod meeting held in 1993. A major focus of the workshop was trophic ecology and the use of a variety of tools that can be applied in Southern Ocean trophic studies for both cephalopod and predator researchers. New tools that are being used as trophic indicators and tracers in food chain pathways include stable isotope, heavy metal and fatty acid signature analysis. Progress is also being made on understanding squid population dynamics in relation to other key components of the ecosystem by incorporating squid data in ecosystem models. Genetic barcoding is now of great value to fish taxonomy as well as other groups and it is expected that a cephalopod barcoding initiative will be an important tool for cephalopod taxonomy. There is a current initiative to produce a new cephalopod beak identification guide to assist predator biologists in identifying cephalopod prey items. There were also general discussions on specific taxonomic issues, Southern Ocean Cephalopod paralarvae and parasites, and suggestions for future CIAC workshop topics.

Keywords: Southern Ocean cephalopods; Trophic indicators; Squid population dynamics; Genetic barcoding; Cephalopod beak identification 


\section{Introduction}

A two day workshop on Southern Ocean cephalopods was held in Hobart, Tasmania, Australia prior to the triennial 2006 Cephalopod International Advisory Council (CIAC) symposium. This provided a forum to specifically discuss issues in relation to Southern Ocean cephalopods that have developed since the last meeting devoted to this species group held in Cambridge, United Kingdom in 1993 (Rodhouse et al. 1994). The workshop provided an excellent cross section of expertise with 13 countries represented with a broad range of researchers from early career scientists to senior researchers.

A particular area of interest was the variety of available techniques that can enhance the study of Southern Ocean cephalopods. The theme of the workshop was ecological with a specific focus on the importance of cephalopods in the food chain. New tools were therefore discussed that can be used to understand the role of cephalopods as predators and to more accurately designate where they fit in the food chain. Signature fatty acid and stable isotope analyses are proving to be ideal techniques for enhancing our understanding of the diets of cephalopods, and stable isotope analysis can even be used as a marker or fingerprint for identifying what water masses an individual has inhabited. Southern Ocean Cephalopods also play a critical role in predator studies, and many serve as important prey species for a variety of vertebrate predators. Developing tools for identifying cephalopods as prey are also needed. Heavy metals can serve a useful purpose in predator tissue analysis for identifying a cephalopod-based versus a fish-based diet. Beak analysis has been an important tool for many years and better identification is currently needed to move this field forward.

The workshop venue also served as a forum to discuss the usefulness of applying molecular techniques to cephalopod taxonomy and there is great potential for initiating a cephalopod barcode of life program. Developing such a data base could serve an important role for identifying species from tissue fragments (e.g., in predator studies). It is critical to increase our knowledge regarding the role of cephalopods in the ecosystem dynamics of the Southern Ocean. An important aspect to this will be incorporating cephalopods into ecosystem models and the workshop took a first step at incorporating squid in the larger ecosystem modeling process.

The following sections provide a synopsis of some of the important tools and initiatives that are being undertaken that will facilitate Southern Ocean cephalopod research as well as research into cephalopods generally. These overviews are designed to provide background 
information on these new and evolving techniques as well as provide examples of how these developing technologies can be applied to Southern Ocean cephalopod biology.

\section{Stable isotopes and the trophic ecology of Southern Ocean Cephalopods-Y. Cherel}

Our knowledge on the food and feeding ecology of cephalopods is mainly restricted to commercial species, including neritic octopuses, cuttlefishes and loliginids, and squids of the family Ommastrephidae (Rodhouse and Nigmatullin 1996). In the Southern Ocean, the dietary habits of only two species has been investigated, the ommastrephid Martialia hyadesi (Rodhouse et al. 1992; Ivanovic et al. 1998; Dickson et al. 2004) and the onychoteuthid Moroteuthis ingens, a common trawl bycatch (Jackson et al. 1998; Phillips et al. 2001, 2003a,b,c; Cherel and Duhamel 2003). Other information is scattered in the literature or nonexistent. Clearly, much more work is needed on the cephalopod trophic relationships for a better understanding of their role in the marine ecosystems of the Southern Ocean and elsewhere.

Until now, stomach content analysis was the main method used to study the diet of cephalopods. The technique allows prey determination at the species level, using hard parts that resist digestion such as crustacean exoskeletons, cephalopod beaks, and fish otoliths and bones. However, stomach content analysis is time consuming and prey determination is often difficult, because cephalopods tear prey into small pieces by their chitinous beaks and items are often too digested. Another major limitation is that stomach contents represent the last feeding events with no indication of long-term dietary habits. This poor temporal integration requires new indirect methods to complement the direct analysis of stomach contents, e.g. signature lipids as trophic markers and stable isotopes.

Since the stable isotopic signature of a consumer reflects that of its diet, stable isotope ratios of carbon $\left({ }^{13} \mathrm{C} /{ }^{12} \mathrm{C}, \delta^{13} \mathrm{C}\right)$ and nitrogen $\left({ }^{15} \mathrm{~N} /{ }^{14} \mathrm{~N}, \delta^{15} \mathrm{~N}\right)$ in proteins have been used extensively to trace pathways of organic matter among organisms (Kelly 2000). Consumers are enriched in ${ }^{15} \mathrm{~N}$ relative to their food (mean value: 2.5-3.4\&; Minagawa and Wada 1984; Vanderklift and Ponsard 2003) and consequently $\delta^{15} \mathrm{~N}$ measurements serve as indicators of a consumer trophic position (Hobson and Welch 1992). By contrast, $\delta^{13} \mathrm{C}$ values vary little along the food chain and are mainly used to determine primary sources in a trophic network. In the marine environment, $\delta^{13} \mathrm{C}$ values indicate the lower- versus higher-latitude plankton, and inshore versus offshore, or pelagic versus benthic contribution to food intake (Hobson et al. 1994; Cherel et al. 2000). Feeding experiments have shown that the turnover rate of isotopes in 
a given tissue is a product of that tissue's protein turnover rate and accretion. Thus, a key issue is that different tissues provide dietary information that is integrated over different time scales. For instance, in birds, liver has a higher turnover rate than blood and muscle, which in turn has higher turnover rates than bone collagen (Hobson and Clark 1992).

Almost no information is available on the stable isotopic signatures of cephalopods, but two preliminary studies underlined the potential of that method to investigate their trophic position and migration (Takai et al. 2000; Cherel and Hobson 2005). As expected, the $\delta^{13} \mathrm{C}$ values of squids show a negative correlation with the latitude of the sampling locations (Takai et al. 2000), reflecting the known latitudinal characteristic of phytoplankton $\delta^{13} \mathrm{C}$ that is wellmarked in the Southern Ocean (Trull and Armand 2001). This feature has been used to characterize the migratory behaviour from Antarctic and subtropical waters to the Polar Frontal Zone of two different squid species caught in Kerguelen waters (Cherel and Hobson 2005). Ontogenic feeding shifts from small, lower trophic level prey of juveniles to large, higher trophic level prey eaten by adults is demonstrated by a progressive increase in $\delta^{15} \mathrm{~N}$ values of cephalopods as they grow (Cherel and Hobson 2005). Furthermore Cherel and Hobson (2005) is the first study to explore the trophic structure of the cephalopod community along with individual squid dietary specialization in their growing/feeding areas. These examples illustrate the usefulness of the method to disentangle trophic relationships at different integrative biological levels, from individuals to ecosystems.

What are the most suitable tissues for stable isotope studies on cephalopods? Muscle tissues are standard tissues for determining the isotopic signature of consumers (Hobson et al. 1994; Kelly 2000). In cephalopods, the use of muscle tissues necessitates collecting whole specimens in the wild, a main limitation due to the paucity of scientific surveys devoted to the group and our inadequacy in catching oceanic and deep-sea species. On the other hand, many marine predators feed upon cephalopods and, because their chitinous beaks are hard structures that resist digestion, hundreds to thousands of them are easily available when analysing stomach contents from marine mammals, seabirds and large predatory bony fishes and sharks (Clarke 1980; Cherel et al. 2004; Imber 1992). Thus, combining the use of predators as biological samplers with measurements of the stable isotopic signature of beaks is a promising tool to investigate the feeding ecology of poorly known cephalopod taxa (Cherel and Hobson 2005). Preliminary investigations, however, showed that beaks are impoverished in ${ }^{15} \mathrm{~N}$, but not in ${ }^{13} \mathrm{C}$, when compared to muscle tissues, the most likely explanation being the presence of chitin in beaks (Cherel and Hobson 2005; Hobson and Cherel 2006). Consequently, caution must be made when using the $\delta^{15} \mathrm{~N}$ values of beaks and those of other tissues from cephalopods and 
other organisms to clarify the trophic structure and dynamics of marine systems. This does not preclude however comparing the isotopic signature of beaks between individuals and species of cephalopods.

In summary, both muscle tissues and beaks are valuable tissues for stable isotope work by cephalopod and predator biologists, respectively. Mantle muscle is the best standard tissue for sampling in cephalopods. In predator stomach samples, however, cephalopods are generally broken into several pieces with head and mantle detached. This makes it generally impossible to sample mantle tissue from predator samples for isotope analysis. However, whole buccal masses (buccal mass + beaks + radula) are often intact in predators stomachs and thus buccal mass is likely to be the best muscle tissue to use from stomach contents. To synthesize and compare data collected by both cephalopod and predator biologists, we suggest that the former measure stable isotopes at least on muscles from both the mantle and buccal mass, and the latter on both the buccal mass and lower beaks.

The widespread application of stable isotope analysis among studies depends in part on the consistency and suitability of the techniques employed by various researchers. Therefore, three important steps have to be taken into account before measuring stable isotopes: the storage of samples, their homogenisation, and lipid removal.

Freezing and freeze-drying are the best preservation methods that do not affect stable isotope ratios of carbon and nitrogen (Bosley and Wainright 1999). Ethanol (70\%) may affect the carbon signature in fatty tissues, but as lipids have to be removed (see below), ethanol is probably the easiest and simplest way to preserve and transport samples. On the other hand, the use of formaldehyde is prohibited because fixation and preservation of samples in formaldehyde significantly affect both their carbon and nitrogen signatures (Hobson et al. 1997; Bosley and Wainright 1999; Edwards et al. 2002; Sarakinos et al. 2002).

Stable isotope analysis requires only small amounts of dry matter (1-2 mg) and thus, homogenisation of the samples is the second crucial aspect of sample preparation to consider. As different tissues have different turnover times and therefore potentially different isotopic signatures, homogenisation of the whole organism is not recommended as within sample variability and dietary information may be lost. It is always preferable to compare the same tissue type among individuals and species (mantle, buccal mass or lower beak). Finally, since lipids are depleted in ${ }^{13} \mathrm{C}$ relative to proteins (Tieszen et al. 1983; Thompson et al. 2000) and biological tissues frequently vary in their lipid content, lipid enriched tissues are more depleted in ${ }^{13} \mathrm{C}$ than lean tissues. For this reason lipids must be extracted to reduce variability attributed to differences in lipid content among tissues. Cephalopod muscle tissues generally have a low 
lipid content (Phillips et al. 2002). However, because muscle tissues from other organisms can be lipid-enriched, routinely extracting lipids from cephalopod tissues (except the beaks), will allow for a non-lipid biased comparison between organisms and studies.

Future scope

Preliminary research on the stable isotopic signature of cephalopod tissues have proved that the method is a useful tool to investigate their trophic interactions and role in marine ecosystems. Much more information, however, is needed to validate its use on cephalopods. It would be especially useful to raise cephalopods in captivity on a constant diet of known isotopic signatures to investigate the enrichment factors between food and tissues, as well as protein turnover and accretion rates in those tissues (Hobson and Cherel 2006; Stowasser et al. 2006). Finally, our understanding of the food and feeding ecology of cephalopods would benefit by a combined approach on the same individual, using stomach content analysis; stable isotope signatures of mantle tissues and beaks; and signature lipid analysis of their digestive glands.

During the course of the discussion at the workshop it was also highlighted that there are some archives of Southern Ocean Cephalopod tissues that have only ever been preserved in alcohol including some from the 19th century held at the Smithsonian Institution, USA. However, it would be necessary to explore if different alcohols may influence stable isotope readings. There are also dried beaks and even eye lenses available at some UK museums. These samples could prove valuable to look at trophic dynamics of cephalopods from previous periods or to detect changes in trophic feeding structure in relation to environmental change.

\section{Signature lipids and fatty acids in trophic studies of Southern Ocean squid-K. Phillips, H. Pethybridge, C. Jackson, G. Jackson and P.D. Nichols}

The application of fatty acids as dietary tracers has occurred since the 1960's (Ackman and Eaton 1966; Sargent 1976), with the technique used to explore dietary relationships in a number of diverse marine organisms (Mourente and Tocher 1993; Graeve et al. 1994; Kirsch et al. 1998; Cripps et al. 1999; Navarro and Villanueva 2000). The approach is based on the assumption that many fatty acids in the marine environment, particularly polyunsaturated fatty acids (PUFA), can only be biosynthesised by certain phytoplankton and macroalgae species and become essential dietary components to higher trophic levels. Phytoplankton and macroalgae species are often characterised by very distinct ratios of fatty acids, and these ratios 
influence the fatty acid profiles of higher organisms and are thus useful tools for providing information on food webs (Graeve et al. 2002).

The digestive gland (DG) of cephalopods is an ideal source of fatty acid dietary tracers, as dietary lipid is deposited in this tissue with limited modification (Phillips et al. 2001). Analyses of total lipid and lipid class composition of the DG of selected cephalopods revealed that lipid stored in this organ is unlikely to be mobilised during sexual maturation (Blanchier and Boucaud-Camou 1984; Clarke et al. 1994) or long-term starvation (Castro et al. 1992). Digestive gland fatty acid profiles have therefore been used to identify important prey groups of the Southern Ocean squid Moroteuthis ingens (Phillips et al. 2001).

It is more difficult to interpret the influence of diet on fatty acid composition in a tissue where biosynthesis and modification of fatty acids occurs, such as in the muscle or blubber tissue of marine vertebrates. Conflicting evidence exists in the literature about the effectiveness of deriving dietary information of marine vertebrates, principally pinnipeds, from fatty acid analyses (Grahl-Nielsen and Mjaavatten 1991; Grahl-Nielsen 1999; Smith et al. 1997; Smith et al. 1999). However, over the past decade the signature lipid approach has been increasingly applied to dietary studies of marine vertebrates, as at-sea foraging data is very difficult to obtain from conventional methods. Analyses are conducted on milk or blubber samples, so intrusive techniques such as stomach lavage and lethal sampling are not required. While many marine vertebrates (including pinnipeds) prey on cephalopods, few data are available on the fatty acid composition of squid for inclusion in such predator-prey comparisons.

In this section we provide an overview of signature lipid methodology in applications with Southern Ocean squid, and in addition provide selected case study findings for Moroteuthis ingens and Todarodes filippovae. The collection details of squid and potential prey items have been validated previously (Phillips et al. 2001; Pethybridge 2004; Jackson 2005). For lipid profiling, all squid were frozen after collection at $-20^{\circ} \mathrm{C}$ and returned to Hobart for dissection and analysis. A number of protocols are used in signature lipid studies, and comparison of the various methodologies is beyond the scope of this overview and will not be covered here. An overview of the protocol used in CSIRO/University of Tasmania studies is provided in Fig. 1 and details of the methods used for the lipid class and fatty acid can be found in Volkman and Nichols (1991) and Phillips et al. (2001).

Case study (1) Moroteuthis ingens - the digestive gland (DG) as a source of fatty acid dietary tracers Mantle is low in lipid, with lipid content $1.5 \pm 0.1 \%$ wet mass in $M$. ingens from Macquarie Island. The major lipid class was phospholipid (PL), present at $83.1 \%$ of total lipids. Sterol (ST), 12.3\%) represented the only other lipid class with values $>3 \%$ of total lipid. 
Polyunsaturated fatty acids (PUFA) were the most abundant class of fatty acids in mantle, at $53.1 \pm 1.6 \%$. PUFA comprised mainly eicosapentaenoic acid (EPA) (20:5n3) and docosahexaenoic acid (DHA) (22:6n3); no other PUFA exceeded 5\%. Saturated fatty acids (SAT) were dominated by 16:0, and summed $31 \pm 0.7 \%$. Monounsaturated fatty acids (MUFA) comprised $15.5 \pm 1.4 \%$, and were represented largely by $20: 1 \mathrm{n} 9$.

In comparison to mantle, the DG lipid content $(26.8 \pm 12.9 \%)$ was generally an order of magnitude greater than the mantle. Triacylglycerol (TAG) was the major class $(75.0 \pm 17.5 \%$ of lipid). Major fatty acids in the DG were 16:0, 18:1n9 and 20:1n9, with MUFA as the major class. The fatty acid profiles of the DG of $M$. ingens grouped with those of the stomach fluid and selected myctophid species in multivariate analyses indicating that the DG is a source of dietary fatty acids. Krill, proposed to be a dietary component of $M$. ingens, was well separated in the multivariate analysis. For $M$. ingens, the application of the signature lipid approach has been used further to examine temporal, spatial and size-related variations in diet (Phillips et al. 2001; 2002, 2003a, b).

The lipid content of the DG of $M$. ingens greatly exceeds that of the mantle. Therefore, fatty acids in the DG derived from this sub-Antarctic squid are in greater absolute abundance than fatty acids in the mantle. A squid predator would ingest more lipid from secondary prey items, which has been stored in the DG of the squid, than from the squid mantle.

In the context of dietary lipid studies of higher predators, blubber, milk and muscle from a range of species have been analysed with the aim of identifying prey groups (Horgan and Barrett 1985; Iverson 1993; Kirsch et al. 1995; Smith et al. 1997; Raclot et al. 1998). However, when squid data have been included in these analyses, it is unclear whether fatty acid data were obtained from whole homogenised squid, flesh tissue only, or from squid remains retrieved from stomach contents of a predator. If squid is low in lipid content (around 1\% wet mass) and dominated by PUFA (Iverson 1993; Iverson et al. 1997), it is likely to have been extracted from flesh only. Based on our findings for $M$. ingens and other species of Southern Ocean squid (Phillips et al. 2002), squid flesh data alone is not suitable for inclusion in these analyses. Such data does not represent the overall lipid composition of a squid as ingested by a predator, and consequently it is highly likely that squid will be interpreted as having little importance in the diet.

When whole, homogenised squid are used to represent potential prey items in fatty acid studies of higher predators, it will be important to consider the large amount of "secondary" fatty acids stored in the DG. Squid may not be effectively represented as a distinct prey group in analyses as their lipid signature may be very similar to (or in the case of lipid-rich species, 
masked by) other potential prey items such as myctophid fish. Therefore, the dietary importance of squid as a prey group may be difficult to interpret and isolate from other prey groups. These implications could constrain the use of fatty acids to assess the importance, or inclusion over space and time, of squid prey items in the diet of higher predators. Given the fact that our general knowledge of squid trophodynamics in the Southern Ocean is poor, it is important to identify and attempt to understand such biases associated with food-web studies. A combination of techniques, such as fatty acid analysis of blubber or muscle, including individual lipid classes (e.g. PL, TAG, wax ester, the latter including fatty alcohol profiling), and DNA analysis of stomach contents or faecal remains, may provide a more robust representation of the inclusion of squid in the diets of higher predators.

Case study (2) Todarodes filippovae - fatty acid dietary tracers and reproductive partitioning

A similar approach to that used for $M$. ingens was applied to the ommastrephid squid $T$. filippovae, together with selected prey items, collected from waters off eastern and southern Tasmania. The lipid class and fatty acid profiles were analysed for 43 squid from three sites. As for M. ingens, mantle tissue was low in lipid $(0.8 \pm 0.5 \%)$, and contained high levels of PL and PUFA. The DG contained markedly higher oil content $(14.8 \pm 7.9 \%)$ and was rich in TAG and MUFA. Using multidimensional scaling (MDS) analysis, the signature fatty acid profiles of the DG of T. filippovae grouped with profiles of myctopids and squid, supporting the findings of stomach content analyses (Pethybridge 2004). No evidence was obtained for size, maturity, spatial or temporal differences in diet, indicating that $T$. filippovae are opportunistic generalist feeders.

We also examined the role of lipid in the maternal reproductive process for $T$. filippovae. We aimed to determine whether lipid is a storage substrate for utilization during reproduction, including examining (i) ovarian oocytes and ovulated eggs, and (ii) whether temporal variation in reproductive condition may be related to egg quality. A two-fold increase in lipid content of ovary was observed with maturation (Fig. 2). PUFA dominated with high PL also observed; these findings highlight the importance of lipid in embryonic development. No diversion of energy from mantle or DG occurred during maturation, suggesting limited evidence for lipid reserves being used as an energy reserve for reproduction. Energy reserves commonly present in fish (e.g. TAG) were low or absent in the ovary and oviduct, which comprised up to $90 \% \mathrm{PL}$ and around $10 \%$ sterol. The quality of ovarian oocytes and ovulated eggs of T. filippovae, in terms of the fatty acid profile, was conserved between seasons. 
Future scope

We observed large amounts of dietary lipid in the DG of two important Southern Ocean squid. Dietary information can be obtained through comparison of the fatty acid profiles of squid DG and prey species. Important implications for the use of fatty acids as dietary tracers in food-webs associated with squid are:

a. The technique has promise for applications to dietary studies of squid, as DG lipid content provides a history of prey fatty acids consumed over a period of time and thus eliminates possible biases associated with instantaneous sampling of diet,

b. Due to the abundance of prey lipids in the DG of selected squid, (that exceed mantle lipid content by more than an order of magnitude), it is important to consider the type of squid fatty acid data included in dietary studies of higher predators. Squid may not be identifiable as a separate group in such analyses, but may be grouped with major prey species such as myctophid fish. Thus food-web studies based on fatty acid analyses may become more difficult to interpret at

higher trophic levels.

\section{Heavy metals in trophic/population studies-P. Bustamante}

Most metals are found in very low concentrations in the environment and in marine animals, and are therefore often considered as trace elements. All are natural but differ in being either essential or non-essential in living organisms. All metals can become toxic above a certain concentration and they bioaccumulate in storage tissues/organs at different rates with some organs concentrating certain metals. The bioaccumulation of trace elements in marine organisms occurs in one of two pathways, either from the surrounding seawater, which would reflect their concentrations in the environment, or from the ingested particulate material (e.g. food), which would reflect the concentrations in the prey.

The transfer of trace elements through the food web can have three different patterns: (1) a decrease in concentration with the increasing trophic level, (2) similar concentrations in the prey and their predators and (3) an increase in the concentration with increasing trophic level, leading to the bioamplification or biomagnification of the element. Overall, this transfer depends firstly, on the specific metal and its physico-chemical form which determines its bioavailability to the upper level (Wallace and Lopez 1997) and secondly, the biology and 
physiology particular to the organism, as different species have different uptake and detoxification strategies influencing the level of metal retention (Rainbow 2000). For example, in contrast to inorganic mercury, this metal under its methylated form is readily bioamplificated along the food webs (Cossa et al. 1990). This is due to the high liposolubilty of methyl-mercury resulting in its enhanced penetration through lipid membranes (Boudou et al. 1983). A particular metal of interest to cephalopod studies is cadmium. Indeed, this metal is highly bioaccumulated by cephalopods because it is efficiently absorbed and retained in their digestive gland (Bustamante et al. 1998; 2002a) but not in decapod crustacean, salps or fish because cadmium is either poorly taken up or highly excreted in these species (Rainbow 2000; Zauke et al. 1999).

Even though metals are generally considered for their potential toxicity in ecotoxicological studies and biomonitoring surveys, there is increasing interest in their use for providing information on life history and trophic ecology of various marine animals, such as sponges, molluscs, fish, seabirds, or mammals. In this respect, chemical analyses in stable/hard structures have received considerable attention in order to get valuable information on population structure and movements of individuals. This is based on the assumptions that these structures grow continuously throughout life, and that their elemental composition is a permanent record of exogenous (and endogenous) factors. In the calcified tissues, i.e. aragonite for fish otoliths and cephalopod statoliths; and hydroxyapatite for mammal teeth, several elements have been reported to be discriminators, belonging to three groups: (1) $\mathrm{Ca}$ and atomic equivalents (2) heavy metals and (3) the monovalent elements (i.e. chlorine, bromine, sodium, potassium, lithium). Various environmental factors can influence the composition of otoliths and statoliths with ambient temperature during uptake correlating with ${ }^{18} \mathrm{O} /{ }^{16} \mathrm{O}$ ratios, and potentially influencing strontium and Sr/Ca ratios (Radtke 1989; Ikeda et al. 1998), and potassium and sodium concentrations (Kalish 1989). Salinity also correlates with strontium, and $\mathrm{Sr} / \mathrm{Ca}$ is a good marker of anadromy forfish (Secor et al. 1995). However, for exothermic animals, the influence of physiological factors is more difficult to assess, particularly the contribution of the waterborne and the diet pathways on elements other than strontium (Geffen et al. 1998). The relatively poor associations reported between the elemental composition and the exposure could be partly due to instrumental inaccuracies and the focus on the most abundant elements (Thresher 1999).

In parallel to investigations on stable tissues, metal analysis in the soft tissues has also been used to infer the population movements and migration in different marine species (e.g. Ichihaschi et al. 2003; Lahaye et al. 2005). In this respect, a multivariate analysis approach of 
trace element contents in cephalopods enabled the discrimination of geographical origin and the inferring of migratory routes (Ichihaschi et al. 2003). Because cephalopods are short-lived, they may accurately and rapidly reflect variations in the elemental composition of their environment (Stowasser et al. 2005; Miramand et al. 2006).

Trace elements and metals can also be used to study the feeding ecology of marine animals. This approach also received increasing interest and is particularly appropriate for large marine predators such fish, birds and mammals which are highly mobile, often protected and therefore difficult to study through classic approaches(Das et al. 2000; Bustamante et al. 2004; Dehn et al. 2005; Lahaye et al. 2005). Metals used in feeding ecology studies can be separated between firstly, those indicating anthropogenic contamination such as vanadium for oil spills, lead for leaded gasoline, and secondly, those indicating a specialised diet or feeding habit in natural conditions, such as cadmium reflecting the consumption of cephalopods, mercury reflecting the consumption of deep water prey and silver reflecting the consumption of benthic organisms (Monteiro et al. 1992; Bustamante et al. 1998, 2004; Dehn et al. 2005).

Metal concentrations in marine top predators are influenced by biological factors of which age is the most important, and by environmental factors such as the geographical origin, the habitat and dietary preferences. The concentrations of cadmium could reach extremely high levels in the kidneys of seabirds and marine mammals, especially in those from high latitudes. Cephalopod consumption has been suggested to be responsible for such elevated concentrations (e.g. Caurant and Amiard-Triquet 1995, Bustamante et al. 1998). This is supported by the clearly higher cadmium concentrations in cephalopods in comparison to most of the other prey species in a single area, and the high proportion of this metal in a bioavailable form for the upper trophic level (Bustamante et al. 2002b). In a same region, cephalopod consumption can also discriminate habitat use by a single species. This approach facilitated the discrimination of two groups of dolphins in the same genetic population. Thus cadmium appears to be a good long term marker of predators feeding on coastal species and those feeding on oceanic ones (Lahaye et al. 2005). Habitat use could also be addressed using mercury in both teuthophageous and non-teuthophageous predators. For example, fish (i.e. swordfish) and seabirds (e.g. albatrosses and petrels) feeding on mesopelagic prey exhibit higher mercury concentrations compared to other seabird species that feed on epipelagic prey (Ochoa-acuña et al. 2002; Kojadinovic et al. 2006). This is because mesopelagic prey has enhanced mercury concentrations in their tissues (Monteiro et al. 1992; Bustamante et al. 2006). 
Analyses of trace elements and metals in hard and soft tissues of marine animals provide complementary tools to standard methods used to investigate the structure of populations, the movements and migrations of individuals and their feeding ecology. The use of heavy metal analysis in cephalopods and their predators has received increasing interest during the last decade and promises to be of increasing use in the future in remote Southern Ocean regions.

\section{Investigating the role of squids in marine food webs through an ecosystem model approach-E.P.M. Grist, E.A. Fulton, G.D. Jackson}

Dynamic ecological models are shaped by specific questions but fall into two general classes: (1) conceptual, qualitative, or mechanistic abstractions which address strategic issues or (2) complex representations which attempt to emulate the real world by producing a 'virtual' simulation world. In all cases it is necessary to identify key biological and physical features as well as appropriate temporal and spatial scales for the dynamic processes of interest. A decision has to be made on the detail that is necessary to achieve what is perceived as an 'optimal' model for a given set of questions. This may typically take the form of a perceived 'trade off' between the number of species to be incorporated and the amount of detail that should be used to represent them, as shown schematically in Fig. 3.

Recent advances in computational power have meant that it is now possible to build highly complex ecological representations which permit longer term projections of population, community and ecosystem dynamics to be made under a variety of possible future scenarios. Their application to marine ecosystems in the fisheries context has resulted in the 'ecosystem model approach' which provides a computational management tool for management strategy evaluation (MSE), whereby a range of management decision processes are evaluated in advance before their possible implementation.

Atlantis framework

An area of special research interest centres on marine food webs that typically involve many indirect interactions that are highly nonlinear between different functional groups. The pivotal role occupied by squids as both predator and prey in marine ecosystems remains poorly understood because of the many connections with different trophic groups and the complexity of the ecological dynamics which they imply (Gurney and Nisbet 1998). In this section we 
consider how the role of squids may be assessed using an ecosystem approach based on the Atlantis framework (Fulton et al. 2004). The framework represents a natural ecosystem using a nutrient-based biogeochemical model that is coupled in the biological/physical sense through differential equations, with linkages between biological groups both spatially and physiologically resolved. It depicts the ecosystem together with anthropogenic (primarily fisheries) activities and any effects that may impact upon it.

A main component within the Atlantis framework is the food web defined between the various functional groups. The vertebrate and cephalopod groups incorporate age-structure whereas other groups are more concisely handled as biomass pools. Production, consumption and growth, habitat dependency, reproduction, movement and large-scale migration, predation and other forms of mortality (such as disease) and waste production are all handled explicitly. This ecology is set in an environmental context using a physical transport model within a polygonal box geometry (Fig. 4) that has multiple layers per box. Physical properties (e.g. depth, seabed type, porosity, salinity, and temperature) are defined for each box (and may change dynamically through time) and transport between boxes (or water column layers within a box) represents processes such as advection, diffusion, settling, mixing and re-suspension. The model is also driven using irradiance and point source input time series, along with exchanges with the atmospheric and oceanic boundary boxes.

The anthropogenic components of the Atlantis framework consist of fisheries, sampling, assessment, and management sub-models. The assessment sub-model includes a variety of the typical fisheries assessment methods from simple catch curve analysis to more complicated approaches such as Virtual Population Analysis. The results of these assessments feed into the management model, which includes all major management levers of interest in the study area, including: spatial and temporal closures; gear, vessel and trip restrictions; by-catch mitigation; escapement; quotas (total, basket, companion or regional); target and protected-endangeredthreatened species considerations. The management levers can be employed to vary fleet-tofleet within the fisheries sub-model and compliance with management need not be complete.

Example application

To demonstrate the scope of the Atlantis framework we provide a simple example in which the effect of anthropogenic finfish fishing mortality on the Bass Strait in south east Australia eco-region is investigated. We consider a hypothetical scenario in which the fishing effort is applied in an intensity equivalent to that which has historically been applied to the 
North Sea in Northern Europe. How would this anthropogenic pressure be predicted to affect the various trophic abundances and food web linkages present in the marine ecosystem? Figure $5 a, b$ show the projected food web structure after running the Atlantis framework to equilibrium both before and after the effects of the fishing pressure have been applied. In this schematic diagram, the area of each box is proportional to the equilibrium biomass of the associated functional group with rectangular boxes for invertebrates and trapeziums for vertebrates showing their age/size structure composition. The thickness of the connecting arrows is proportional to the biomass flows between the various groups to which they connect. Comparison of these two figures in particular shows that the predicted effect of the fishing pressure would be to shift the equilibrium of the ecosystem so that a major increase in squid and jellies biomass occurs. There is also a predicted decrease in demersal and pelagic fish abundances, both in terms of overall biomass and a reduction of larger size classes, as indicated by the absence of basal portions of the corresponding trapeziums. Additionally, some of the main predator-prey interactions and biomass flows as indicated by the changes in arrows between the groups are altered.

Calibration is achieved by a comparison of model output with time series data obtained for specific groups or species from historic catch or survey data. Although the example considered here is conjectural, the approach has been used to validate the model when applied to a range of management scenarios on different spatial and temporal scales. For example, in a representation of the Georges Bank, Northern California Current (Brand et al. 2006) and the New SouthWales and broader regional south east Australian marine ecosystems, the predictive capacity was verifiably demonstrated to be accurate in terms of generating historically accurate projections for all of the commercially targeted fish species. For groups which had patchier historic time series, there was still a match in terms of trends and order of magnitude, but the overall fit was not as tight as for groups with good historical data. Poorer levels of available data for these groups implied less overall information, but the matching of trends was still considered significant given the management strategy evaluation framework within which the model is typically applied.

\section{Future scope}

The Atlantis framework is a system which enables a wide range of questions to be addressed. An intended future application will be to tailor the framework to a squid-centred design that will assist with Australian arrow squid stock assessment in southeast Australia. This 
will be achieved by reducing the spatial domain of interest and compressing the corresponding marine food web to an appropriate 'squidcentric' subweb, such as that shown in Fig. 6.

The framework will then be used to quantify the inter-reliance of squid stocks in different management areas and provide projections of the effects of fluctuations in both environment and fishing effort on squid recruitment size and seasonal timing. At the same time, this will provide insights into the general significance of squids within marine ecosystem dynamics that would otherwise remain unknown.

\section{DNA Barcoding the fishes of the world-R.D. Ward}

DNA sequence analysis has been used for over 30 years to assist species identifications, but different sequences have been used for different groups and in different laboratories. Recently, Hebert et al. (2003) proposed that a single gene sequence, an approximately 655 base pair region of the mitochondrial cytochrome oxidase gene (COI), would differentiate all, or at least the vast majority of, animal species. The sequence of this region was likened to a barcode, with each species being delineated by a single sequence or a tight cluster of very similar sequences (see Fig. 7). The concept and development of fish barcoding is discussed in this section. This provides a framework for how such a technique could be used to discriminate cephalopods of which there are far fewer species.

The concept of species barcodes fired the imagination of many scientists around the world. In spring 2004 (see Savolainen et al. 2005), the Sloan Foundation provided an award to establish a secretariat for the 'Barcode of Life' at the Smithsonian National Museum of Natural History (Washington, DC, USA), which in turn led to the creation of the Consortium for the Barcode of Life (www.barcoding.si.edu). At the University of Guelph (Ontario), a barcode database (BOLD, the Barcode of Life Database) was established which permits deposition of sequences, collection information and photographs of specimens, and includes software for preliminary data analysis including tree construction (www.barcodinglife.org). Projects within BOLD can be password-protected if desired and it is straightforward to transfer these sequences to GenBank.

Empirical support for the barcoding concept includes studies of Lepidoptera (Hebert et al. 2004a; Hajibabaei et al. 2006), parasitoid flies (Smith et al. 2006), ants (Smith et al. 2005a), springtails (Hogg and Hebert 2004), frogs (Vences et al. 2005) and birds (Hebert et al. 2004b). 
Does DNA barcoding discriminate fish species? If it does, an open-access web-based library of species barcodes would greatly facilitate the accurate identification of unknown specimens. These unknowns could be whole fish, fillets, fins or fin fragments, juveniles, larvae or individual eggs. It is also possible that the methodology would permit the identification of prey items in stomachs, although this has yet to be confirmed. Deep divergence in COI sequences within a single putative species might flag the discovery of cryptic species.

The ready availability of such a searchable database would have important repercussions for fisheries management, ecosystem research, conservation, and the detection of retail substitutions of species. All that would be necessary for identification would be that a tiny fragment of the unknown specimen be sent to a molecular genetics laboratory for sequencing (using published conserved primers for sequence amplification) and then matched against the on-line database using an on-line search engine.

The first fish barcoding paper was an analysis of 207 species of fish (Ward et al. 2005), mostly Australian marine species and including chaemerids, sharks, rays and teleosts; most species were represented by multiple specimens. The average within-species genetic divergence was very low $(0.39 \%)$, far lower than the average divergence of species within a genus $(9.93 \%)$. All these 207 species could be differentiated by their COI sequence, although single individuals of two species had haplotypes characteristic of a congener. These individuals could reflect haplotype sharing of recently diverged species, hybridisation, or mis-identification: we suspect the latter but unfortunately these specimens were not retained and vouchered and so cannot be re-examined. Data for all these species are available for examination at www.barcodinglife.org.

These few questionable identifications show how important it is that, in the establishment of a reference barcode dataset, as many whole specimens as possible are archived in case questions later arise about identification accuracy. It is essential that geneticists and taxonomists work together closely in the establishment of a barcode database. This is not just for accurate identification of contributing samples, vital though that is, but also for resolution of issues such as whether deep sequence divergence is indeed likely to flag the existence of previously undescribed species.

Subsequently several hundred more Australian fish species have been barcoded with $>99 \%$ species separable. A valuable case-study is provided by the dogfish genus Squalus. Here careful morphological examination of the taxon Squalus mitsukurii in south-east Asian waters revealed a complex of as yet un-named species (Last and Stevens 1994): barcoding confirmed the reality of this species complex. 
Based on an examination of more than 500 fish species, our very firm conclusion is that COI sequencing - barcoding - can be used to identify fish to an extremely high level of accuracy. Further, comparisons with conspecific specimens barcoded from off the South African coasts suggest the existence of a significant amount of cryptic species diversity.

Fish Barcode of Life (FISH-BOL)

Given the early fish results, and the importance of fish species to the global economy, a collaborative venture was established with the aim of barcoding all the fishes of the world. The FishBase global count of fish species in November 2005 was 29,200 (see www.fishbase.org), about $50 \%$ of all vertebrate species, but a manageable number.

Assisted by a grant from the Sloan Foundation, an inaugural FISH-BOL - the Fish Barcode of Life-workshop was held in Guelph in June 2005. The agenda for this workshop, its outcomes, and other information is available at www.fishbol.org.

At the workshop it was decided to establish a chair and a co-chair for each of ten geographic regions. It would be the duty of these chairs and co-chairs to assemble a local working group to facilitate the barcoding of both the marine and freshwater species of that region. Working groups would be expected to include both geneticists and taxonomists. Species lists for each region have been provided courtesy of Nicolas Bailly of FishBase, with these lists partitioned by FAO statistical regions. Initially, the aim is to try to get five individuals of each species barcoded per working group region, and then refine the sampling to include five specimens per FAO region.

Clearly, while we think this project is achievable and desirable, it will cost money and will take some years. Progress in some regions has been slow, reflecting a shortage of funds. As of March 2007, about 3500 species have been barcoded with an average of about four specimens per species. In fact, the actual barcoding is relatively trivial in terms of cost and money. Collection, identification and vouchering of specimens is substantially more labourintensive. While there are large collections of fishes in museums around the world, most of these were collected in the pre-genomics era and have been preserved in formalin. It is possible to get sequence data from formalin-preserved fish, but this is labour-intensive and costly as the sequence data can in generally only be recovered in small sequences of perhaps 100 base pairs and then needs to be assembled. On the other hand, frozen tissue or alcohol-stored tissue can be barcoded for all 655 base pairs in a single run. 
Future scope

The concept of barcoding has significant relevance to cephalopods. There are only about 800 species of cephalopods so barcoding all cephalopods will be a much simpler task than barcoding all fishes. Given the availability of accurately identified barcode-able material, and funds, it should be possible to complete the task in a year or two. Information on COI sequence variation is already available for single individuals of about 40 decapod and octopod species (Carlini et al. 2001; Zheng et al. 2004), and is very largely species-specific (a few Sepiidae of different species appeared to share COI barcodes, Zheng et al. 2004). The topic of a cephalopod barcode of life project (CephalopodBOL) was discussed further during special meetings at the CIAC symposium during the week after the workshop. It is expected that this initiative will continue to move forward.

\section{Cephalopod beak guide for the Southern Ocean-J.C. Xavier and Y. Cherel}

Rationale

As Southern Ocean cephalopods are difficult to catch in nets, most of our knowledge of these molluscs is based on their occurrence in predator diets (Cherel and Klages 1998; Rodhouse and Nigmatullin 1996; Xavier et al. 2002). Cephalopods are eaten in large numbers by seals, seabirds and whales, with an estimated 400,000 tons consumed each year around South Georgia, Crozet and Kerguelen Islands (Clarke 1983; Ridoux 1994). Consequently, much effort has been put into the development of methods to determine the identity and size of cephalopods, based on the morphology of their beaks (Clarke 1966; Clarke 1977; Clarke 1986; Lu and Ickeringill 2002). Presently, there is no published guide directed to identify beaks of cephalopods from the Southern Ocean. The handbook used (Clarke 1986) is now out of print and is in need of revision with additional material. Indeed, various new cephalopod species have been described for the Southern Ocean (e.g. Allcock and Piertney 2002) and taxonomic work has improved their nomenclature (Lipinski 2001). Therefore, it is highly desirable to have a guide that includes all available information on the cephalopod species of the Southern Ocean.

A guide is to be designed to support the analysis of diets of higher predators from the Southern Ocean. We propose the publication of a new photographic guide, in which will include comments on the species beak characteristics, using both upper and lower beaks. This would serve a variety of purposes: (i) to update previous identification guides which are mostly out of 
print, and do not incorporate recent changes in nomenclature and the improved ability to distinguish species with similar beak morphology, (ii) to indicate which species are present, and in what numbers, in the diet of different predators to speed the identification process, (iii) to advance our knowledge in beak identification (as upper and lower beaks are used) particularly useful on predator diets which upper beaks are normally in higher number, (iv) to provide an easily accessible resource for the non-specialist scientists (e.g. new field assistants) and elsewhere, such as research institutes and universities.

The Southern Ocean beak guide will have full coverage of all known species found in the diet of predators in the Southern Ocean. The layout will comprise: (a) A general introduction to the use of squid beaks to characterise predator diet and a description of how to use the guide, (b) Photo images (3 per species, from a high resolution Digital camera) of the lower beaks of all squid and octopod species and of the upper beaks of key /most abundant species, (c) Brief descriptions of the key identification features, (d) A comprehensive key to help readers identify beaks to families/species level, (e) Updated allometric equations to convert beak size to original body mass and size, (f) Updated species nomenclature, (g) Comments on the relative incidence of each species in the diet of particular predators, (h) An indication of the typical beak sizes recorded in the diet of each predator and (f) A bibliography and suggested further reading.

\section{Future scope}

More than 50 cephalopod species, from 24 families (including 5 octopod families), are known to occur around the Southern Ocean (from the Atlantic, Indian and Pacific sectors) and adjacent waters. There is a number of issues that need to be addressed in terms of cephalopod beak identification for the Southern Ocean. Firstly, there is an urgent need for quantitative work on the allometric relationships between beak size and the original mantle length/mass of cephalopods. Even the most abundant species in the Southern Ocean are poorly represented, such as Kondakovia longimana, Galiteuthis glacialis or Mesonychoteuthis hamiltoni. Secondly, various unknown cephalopod beaks are found in Southern Ocean predators but complete animals have never been caught by nets. For example, the morphology of some Southern Ocean cephalopods is still unknown (such as Moroteuthis sp. B (Imber) and Oegopsida sp. A) whose beaks occur in various predators (Fig. 8). Thirdly, as cephalopod beaks are found in a wide range of predator diets and reside there for different lengths of time, they can get heavily eroded and change their shape, making their identification difficult (Xavier et al. 2003). Fourthly, cephalopod beaks of some species may change dramatically their structure as they grow (e.g. 
Moroteuthis ingens). Fifthly, need to improve identification techniques on the identification of cephalopods using upper beaks. Finally, much effort has been put into the systematics of Southern Ocean octopods recently but, out of the around 20 species of octopods known to occur in the region, much taxonomic work still need to be done (including their beaks descriptions). In spite of the problems in studying beaks, the information they can give is extremely valuable. Studies on the diets of cephalopod predators from the Southern Ocean, along with the suggested improvements on cephalopod beaks identification, will enhance our knowledge on cephalopod ecology and stimulate scientific research on this important research area of the biology of the Southern Ocean.

\section{General discussions during the workshop}

A number of other presentations/discussions also took place during the two days of the workshop. These discussions were not formally documented but highlighted the huge potential and continued need for Southern Ocean Cephalopod research.

Eric Hochberg pointed out the great need for parasite studies on cephalopods in the Southern Ocean. Some parasite species may in fact act as a taxonomic voucher for some Antarctic octopod species. For the most part, the Southern Ocean is virtually unstudied in terms of cephalopod parasites and there is thus a huge amount of work to be done in this area and there is also great potential for student projects.

Some taxonomic issues were discussed such as the confusion on the genus Mastigoteuthis versus Idioteuthis. For example, it is unclear at the current time whether the deepwater species captured off Tasmania and New Zealand should be Idioteuthis cordiformis or Mastigoteuthis cordiformis. This is certainly a group that needs more work and the use of genetics would likely help with the taxonomy of this group. It was suggested that at this stage it would be premature to subdivide the Mastigoteuthis genus.

The need for further study into the biology and taxonomy of Southern Ocean juvenile cephalopods was reiterated by Uwe Piatkowski. There is especially a need for more information 
on the young stages of Antarctic squid. Paralarval collections are not really comprehensive enough to identify squid spawning areas. It was suggested that fixing animals in the dark may help to preserve chromatophore patterns and it is best to not use $100 \%$ ethanol. It was even suggested that animals can be frozen in water to preserve chromatophore pattern for drawing. Digital images taken at the time of collection would also greatly aid in identifying species and new digital camera technology is now producing excellent results.

The new initiative of the Census of Antarctic Marine Life (CAML) was presented by Victoria Wadley. This program can provide the basis of a coordinated effort which can help to facilitate Southern Ocean Cephalopod collections in the future. A potential strategy would be to take advantage of existing expeditions that are planned for the Southern Ocean. Future opportunities for cephalopod collections could potentially be coordinated by CAML. Such coordination could involve CAML connecting researchers with appropriate Southern Ocean cruises to facilitate cephalopod collections.

The future

The workshop provided an opportunity to showcase some of the important advances that have been made in the field of Southern Ocean Cephalopod biology since the meeting in Cambridge in 1993. At the same time it revealed that there is still an immense amount of work that needs to be done. Many of the techniques discussed will also serve cephalopod researchers working in other parts of the world outside the Southern Ocean. The large number of scientists in training promises a bright future for cephalopod research in the Southern Ocean. A number of topics were also suggested for potential workshop ideas for the next CIAC meeting to be held in Spain in 2009. Potential areas that would benefit by international discourse as was demonstrated at this workshop include: 
- Cephalopod responses to fisheries and environmental perturbations (e.g., pollution).

- The effects of climate change on cephalopod populations

- Conservation of cephalopods impacted by fisheries

- International bycatch management of cephalopods

- The effects of seismic work on cephalopods and the link to cephalopod mass strandings.

\section{References}

Ackman RG, Eaton CA (1966) Lipids of the fin whale (Balaenoptera physalus) from North Atlantic waters. III. Occurrence of eicosenoic and docosenoic fatty acids in the zooplankter Meganyctiphanes norvegica (M. sars) and their effect on whale oil composition. Can J Biochem 44:1561-1566

Allcock AL, Piertney SB (2002) Evolutionary relationships of Southern Ocean Octopodidade (Cephalopoda: Octopoda) and a new diagnosis of Pareledone. Mar Biol 140:129-135

Blanchier B, Boucaud-Camou E (1984) Lipids in the digestive gland and the gonad of immature and mature Sepia officinalis (Mollusca: Cephalopoda). Mar Biol 80:39-43

Bosley KL, Wainright SC (1999) Effects of preservatives and acidification on the stable isotope ratios $\left({ }^{15} \mathrm{~N}:{ }^{14} \mathrm{~N},{ }^{13} \mathrm{C}:{ }^{12} \mathrm{C}\right)$ of two species of marine animals. Can J Fish Aquat Sci 56:2181-2185

Boudou A, Georgescauld D, Desmazes JP (1983) Ecotoxicological role of the membrane barriers in transport and bioaccumulation of mercury compounds. In: Nriagu JO (ed) Aquatic toxicology. J Wiley and Sons, New York, pp 118-136

Brand EJ, Kaplan IC, Harvey CJ, Fulton EA, Hermann AJ, Field JC, Levin PS (2006) A Spatially Explicit Ecosystem Model of the California current's food web and oceanography. NOAA technical report series

Bustamante P, Caurant F, Fowler SW, Miramand P (1998) Cephalopods as a vector for the transfer of cadmium to top marine predators in the north-east Atlantic Ocean. Sci Total Environ 220:71-80

Bustamante P, Cosson RP, Gallien I, Caurant F, Miramand P (2002b) Cadmium detoxification processes in the digestive gland of cephalopods in relation to accumulated cadmium concentrations. Mar Environ Res 53:227-241

Bustamante P, Lahaye V, Durnez C, Churlaud C, Caurant F (2006) Total and organic Hg concentrations in cephalopods from the North East Atlantic waters: influence of geographical origin and feeding ecology. Sci Total Environ 368:585-596

Bustamante P, Morales CF, Mikkelsen B, Dam M, Caurant F (2004) Trace elements bioaccumulation in the grey seal Halichoerus grypus from the Faroe Islands. Mar Ecol Prog Ser 267:291-301

Bustamante P, Teyssié JL, Fowler SW, Cotret O, Danis B, Miramand P, Warnau M (2002a) Biokinetics of zinc and cadmium accumulation and depuration at different stages in the life cycle of the cuttlefish Sepia officinalis. Mar Ecol Pro Ser 231:167-177

Carlini DB, Young RE, Vecchione M (2001) A molecular phylogeny of the Octopoda (Mollusca: Cephalopoda) evaluated in the light of morphological evidence. Mol Phylogen Evoln 21:388-397

Castro BG, Garrido JI, Sotelo CG (1992) Changes in composition of digestive gland and mantle muscle of the cuttlefish Sepia officinalis during starvation. Mar Biol 114:11-20

Caurant F, Amiard-Triquet C (1995) Cadmium contamination in Pilot Whales Globicephala melas: source and potential hazard to the species. Mar Pollut Bull 30:207-210

Cherel Y, Duhamel G (2003) Diet of the squid Moroteuthis ingens (Teuthoidea: Onychoteuthidae) in the upper slope waters of the Kerguelen Islands. Mar Ecol Prog Ser 250:197-203 
Cherel Y, Duhamel G, Gasco N (2004) Cephalopod fauna of subantarctic islands: new information from predators. Mar Ecol Prog Ser 266:143-156

Cherel Y, Hobson KA (2005) Stable isotopes, beaks and predators: a new tool to study the trophic ecology of cephalopods, including giant and colossal squids. Proc R Soc Lond B 272:1601-1607

Cherel Y, Hobson KA, Weimerskirch H (2000) Using stable-isotope analysis of feathers to distinguish moulting and breeding origins of seabirds. Oecologia 122:155-162

Cherel Y, Klages N (1998) A review of the food of albatrosses. In: Robertson G, Gales R (eds) Albatross biology and conservation. Surrey Beatty and Sons, Chipping Norton, Australia, pp 113-136

Clarke A, Rodhouse PG, Gore DJ (1994) Biochemical composition in relation to the energetics of growth and sexual maturation in the ommastrephid squid Illex argentinus. Phil Trans Roy Soc Lond B 344:201-212

Clarke M (1966) A review of the systematics and ecology of oceanic squids. Adv Mar Biol 4:91-300

Clarke M (1977) Beaks, nets and numbers. Symposium Zool Soc Lond 38:89-126

Clarke MR (1980) Cephalopoda in the diet of sperm whales of the Southern Hemisphere and their bearing on sperm whale biology. Discovery Rep 37:1-324

Clarke MR (1983) Cephalopod biomass-estimation from predation. Mem Natl Mus Victoria 44:95-107

Clarke MR (1986) A handbook for the identification of cephalopod beaks. Clarendon Press, Oxford

Cossa D, Thibaud Y, Rome'o M, Gnassia-Barelli M (1990) Le mercure en milieu marin. Biogéochimie et écotoxicologie. Rapport scientifiques et techniques de l'IFREMER, Brest

Cripps GC, Watkins JL, Hill HJ, Atkinson A (1999) Fatty acid content of Antarctic krill Euphausia superba at South Georgia related to regional populations and variations in diet. Mar Ecol Prog Ser 181:177-188

Das K, Lepoint G, Loizeau V, Debacker V, Dauby P, Bouquegneau JM (2000) Tuna and dolphin associations in the North-East Atlantic: evidence of different ecological niches from stable isotope and heavy metal measurements. Mar Pollut Bull 40(2):102-109

Dehn LA, Sheffield GG, Follmann EH, Duffy LK, Thomas DL, Bratton GR, Taylor RJ, O'Hara TM (2005) Trace elements in tissues of phocid seals harvested in the Alaskan and Canadian Arctic: influence of age and feeding ecology. Can J Zool 83:726-746

Dickson J, Morley SA, Mulvey T (2004) New data on Martialia hyadesi feeding in the Scotia Sea during winter; with emphasis on seasonal and annual variability. J Mar Biol Ass UK 84:785-788

Edwards MS, Turner TF, Sharp Z (2002) Short- and long term effects of fixation and preservation on stable isotope values $\left(\delta^{13} \mathrm{C}, \delta{ }^{15} \mathrm{~N}, \delta^{34} \mathrm{~S}\right)$ of fluid-preserved specimens. Copeia 4:1106-1112

Fulton EA, Parslow JS, Smith ADM, Johnson CR (2004) Biogeochemical marine ecosystem models II: the effect of physiological detail on model performance. Ecol Model 173(4):371-406

Geffen AJ, Pearce NJ, Perkins WT (1998) Metal concentrations in fish otoliths in relation to body composition after laboratory exposure to mercury and lead. Mar Ecol Prog Ser 165:235-245

Graeve M, Kattner G, Hagen W (1994) Diet-induced changes in the fatty acid composition of Arctic herbivorous copepods: experimental evidence of trophic markers. J Exp Mar Biol Ecol 182:97110

Graeve M, Kattner G, Wiencke C, Karsten U (2002) Fatty acid composition of Arctic and Antarctic macroalgae: indicator of phylogenetic and trophic relationships. Mar Ecol Prog Ser 231:67-74

Grahl-Nielsen O (1999) Comment: fatty acid signatures and classification trees: new tools for investigating the foraging ecology of seals. Can J Fish Aquat Sci 56:2219-2223

Grahl-Nielsen O, Mjaavatten O (1991) Dietary influence on fatty acid composition of blubber fat of seals as determined by biopsy: a multivariate approach. Mar Biol 110:59-64

Gurney WSC, Nisbet RM (1998) Ecological Dynamics. Oxford University Press, New York

Hajibabaei M, Janzen DH, Burns JM, Hallwachs W, Hebert PDN (2006) DNA barcodes to distinguish species of tropical Lepidoptera. Proc Natl Acad Sci USA 103:968-971

Hebert PDN, Cywinska A, Ball SL, de Waard JR (2003) Biological identifications through DNA barcodes. Proc Roy Soc Lond B 270:313-322

Hebert PDN, Penton EH, Burns JM, Janzen DH, Hallwachs W (2004a) Ten species in one: DNA barcoding reveals cryptic species in the neotropical skipper butterfly Astraptes fulgerator. Proc Natl Acad Sci USA 101:14812-14817

Hebert PDN, Stoeckle MY, Zemlak TS, Francis CM (2004b) Identification of birds through DNA barcodes. PLoS Biol 2:1657-1663 
Hobson KA, Cherel Y (2006) Isotopic reconstruction of marine food webs using cephalopod beaks: new insight from captively raised Sepia officinalis. Can J Zool 84:766-770

Hobson KA, Clark RW (1992) Assessing avian diets using stable isotopes I: Turnover of ${ }^{13} \mathrm{C}$ in tissues. Condor 94:181-188

Hobson KA, Gibbs HL, Gloutney ML (1997) Preservation of blood and tissue samples for stable-carbon and stable-nitrogen isotope analysis. Can J Zool 75:1720-1723

Hobson KA, Piatt JF, Pitocchelli J (1994) Using stable isotopes to determine seabird trophic relationships. J Anim Ecol 63:786-798

Hobson KA, Welch HE (1992) Determination of trophic relationships within a high Arctic marine food web using $\delta^{13} \mathrm{C}$ and $\delta^{15} \mathrm{~N}$ analysis. Mar Ecol Prog Ser 84:9-18

Hogg ID, Hebert PDN (2004) Biological identification of springtails (Collembola: Hexapoda) from the Canadian Arctic using mitochondrial DNA barcodes. Can J Zool 82:749-754

Horgan IE, Barrett JA (1985) The use of lipid profiles in comparing the diets of seabirds. In: Siegfried WR, Condy PR, Laws RM (eds) Antarctic nutrient cycles and food webs. Springer-Verlag, Berlin, pp 493-497

Ichihashi H, Nakamura Y, Kannan K, Tsumura A, Yamasaki S (2003) Multi-elemental concentrations in tissues of Japanese common squid (Todarodes pacificus). Arch Environ Contam Toxicol 41:483-490

Ikeda Y, Arai N, Sakamoto W, Kidokoro H, Yoshida K (1998) Microchemistry of the statoliths of the Japanese common squid Todarodes pacificus with special reference to its relation to the vertical temperature profiles of squid habitat. Fish Sci 64:179-184

Imber MJ (1992) Cephalopods eaten by wandering albatrosses (Diomedea exulans L.) breeding at six circumpolar localities. J R Soc N Z 22:243-263

Ivanovic ML, Brunetti NE, Elena B, Rossi GR (1998) A contribution to the biology of the ommastrephid squid Martialia hyadesi (Rochebrune and Mabille, 1889) from the southwest Atlantic. S Afr J Mar Sci 20:73-79

Iverson SJ (1993) Milk secretion in marine mammals in relation to foraging: can milk fatty acids predict diet? Symp Zool Soc Lond 66:263-291

Iverson SJ, Frost KJ, Lowry LF (1997) Fatty acid signatures reveal fine scale structure of foraging distribution of harbor seals and their prey in Prince William Sound, Alaska. Mar Ecol Prog Ser 151:255-271

Jackson CH (2005) Reproductive plasticity in Todarodes filippovae. MSc Thesis, University of Tasmania

Jackson GD, McKinnon JF, Lalas C, Ardern R, Buxton NG (1998) Food spectrum of the deepwater squid Moroteuthis ingens (Cephalopoda: Onychoteuthidae) in New Zealand waters. Polar Biol 20:56-65

Kalish JM (1989) Otolith microchemistry: validation of the effects of physiology, age and environment on otolith composition. J Exp Mar Biol Ecol 132:151-178

Kelly JF (2000) Stable isotopes of carbon and nitrogen in the study of avian and mammalian trophic ecology. Can J Zool 78:1-27

Kirsch PE, Iverson SJ, Bowen WD (1995) Diet composition based on fatty acid signatures: captive feeding experiments on harp seals and grey seals. In: Eleventh biennial conference on the biology of marine mammals. Orlando, Florida

Kirsch PE, Iverson SJ, Bowen WD, Kerr SR, Ackman RG (1998) Dietary effects on the fatty acid signature of whole Atlantic cod (Gadus morhua). Can J Fish Aquat Sci 55:1278-1386

Kojadinovic J, Potier M, Le Corre M, Cosson RP, Bustamante P (2006) Mercury content in commercial pelagic fish and its risk assessment in the Western Indian Ocean. Sci Total Environ 366:688-700

Lahaye V, Bustamante P, Spitz J, Das K, Meynier L, Magnin V, Dabin W, Caurant F (2005) Long-term dietary preferences of common dolphins in the Bay of Biscay using a metallic tracer. Mar Ecol Prog Ser 305:275-285 
Last PR, Stevens JD (1994) Sharks and rays of Australia. CSIRO Publishing, Melbourne, Australia, pp 600

Lipinski MP (2001) Preliminary description of two new species of cephalopods (Cephalopoda: Brachioteuthidae) from South Altantic and Antarctic waters. Bull Sea Fish Inst 1:3-14

Lu CC, Ickeringill R (2002) Cephalopod beak identification and biomass estimation techniques: tools for dietary studies of southern Australian finfishes. Mus Vic Sci Rep 6:1-65

Minagawa M, Wada E (1984) Stepwise enrichment of ${ }^{15} \mathrm{~N}$ along food chains: further evidence and the relation between $\delta^{15} \mathrm{~N}$ and animal age. Geochim Cosmochim Acta 48:1135-1140

Miramand P, Bustamante P, Bentley D, Koueta N (2006) Variation of heavy metal concentrations $(\mathrm{Ag}, \mathrm{Cd}, \mathrm{Co}, \mathrm{Cu}, \mathrm{Fe}, \mathrm{Pb}, \mathrm{V}, \mathrm{Zn})$ during the life cycle of the common cuttlefish Sepia officinalis. Sci Total Environ 361:132-143

Monteiro LR, Porteiro FM, Gonc, alves JM (1992) Inter and intra-specific variation of mercury levels in muscle of cephalopods from the Azores. Arquipelago 10:13-22

Mourente G, Tocher DR (1993) The effects of weaning on to a dry pellet diet on brain lipid and fatty acid compositions in post-larval filhead sea bream (Sparus aurata L.). Com Biochem Physio A 104:605-611

Navarro JC, Villanueva R (2000) Lipid and fatty acid composition of early life stages of cephalopods: an approach to their lipid requirements. Aquaculture 183:161-177

Ochoa-Acuña H, Sepulveda MS, Gross TS (2002) Mercury in feathers from Chilean birds: influence of location, feeding strategy, and taxonomic affiliation. Mar Pollut Bull 44:340 345

Pethybridge H (2004) Diet of squid (T. filippovae): lipid and stomach analysis. BSc (Honours) Thesis, University of Tasmania

Phillips KL, Jackson GD, Nichols PD (2001) Predation on myctophids by the squid Moroteuthis ingens around Macquarie and Heard Islands: stomach contents and fatty acid analyses. Mar Ecol Prog Ser 215:179-189

Phillips KL, Nichols PD, Jackson GD (2002) Lipid and fatty acid composition of four southern ocean squid species: implications for food-web studies. Antarct Sci 14:212-200

Phillips KL, Nichols PD, Jackson GD (2003a) Temporal variations in the diet of the squid Moroteuthis ingens at Macquarie Island: stomach contents and fatty acid analyses. Mar Ecol Prog Ser 256:135-149

Phillips KL, Nichols PD, Jackson GD (2003b) Dietary variation of the squid Moroteuthis ingens at four sites in the Southern Ocean: stomach contents, lipid and fatty acid profiles. J Mar Biol Ass UK 83:523-534

Phillips KL, Nichols PD, Jackson GD (2003c) Size-related dietary changes observed in the squid Moroteuthis ingens at the Falkland Islands: stomach contents and fatty-acid analyses. Polar Biol 26:474-485

Raclot T, Groscolas R, Cherel Y (1998) Fatty acid evidence for the importance of myctophid fishes in the diet of King penguins, Aptenodytes patagonicus. Mar Biol 132:523-533

Radtke RL (1989) Strontium-calcium concentration ratios in fish otoliths as environmental indicators. Com Biochem Physiol A 92:189-193

Rainbow PS (2000) Trace metal concentrations in aquatic invertebrates: why and so what? Environ Pollut 120:497-507

Ridoux V (1994) The diets and dietary segregation of seabirds at the Subantarctic Crozet Islands. Marine Ornithol 22:1-192

Rodhouse PG, Nigmatullin CM (1996) Role as consumers. Phil Trans R Soc Lond 351:1003-1022

Rodhouse PG, Piatkowski U, Lu CC (1994) Southern Ocean cephalopods: life cycles and populations. (Proceedings of the symposium held at Kings College Cambridge, 5-9 July 1993). Ant Sci 6:136

Rodhouse PG, White MG, Jones MRR (1992) Trophic relations of the cephalopod Martialia hyadesi (Teuthoidea: Ommastrephidae) at the Antarctic Polar Front, Scotia Sea. Mar Biol 114:415-421 
Sarakinos HC, Johnson ML, Vander Zanden MJ (2002) A synthesis of tissue-preservation effects on carbon and nitrogen stable isotope signatures. Can J Zool 80:381-387

Sargent JR (1976) The structure, metabolism and function of lipids in marine organisms. In: Malins C, Sargent JR (eds) Biochemical and biophysical perspectives in marine biology, vol 3. Academic Press, London, pp 149-212

Savolainen V, Cowan RS, Vogler AP, Roderick GK, Lane R (2005) Towards writing the encyclopaedia of life: an introduction to DNA barcoding. Phil Trans Roy Soc B 360:1805-1811

Secor DH, Henderson-Arzapalo A, Piccoli PM (1995) Can otolith microchemistry chart patterns of migration and habitat utilization in anadromous fishes. J Exp Mar Biol Ecol 192:15-33

Smith MA, Fisher BL, Hebert PDN (2005) DNA barcoding for effective biodiversity assessment of a hyperdiverse arthropod group: the ants of Madagascar. Phil Trans Roy Soc B 360:1825-1834

Smith MA, Woodley NE, Janzen DH, Hallwachs W, Hebert PDN (2006) DNA barcodes reveal cryptic host-specificity within the presumed polyphagous members of a genus of parasitoid flies (Diptera: Tachindae). Proc Natl Acad Sci USA, in press

Smith SJ, Iverson SJ, Bowen WD (1997) Fatty acid signatures and classification trees: new tools for investigating the foraging ecology of seals. Can J Fish Aquat Sci 54:1377-1386

Smith SJ, Iverson SJ, Bowen WD (1999) Reply: fatty acid signatures and classification trees: new tools for investigating the foraging ecology of seals. Can J Fish Aquat Sci 56:2224-2226

Stowasser G, Bustamante P, MacLeod CD, Wang J, Pierce GJ (2005) Spawning areas and toxic element levels in squid (Loligo forbesi) in UK waters, with notes on toxic element levels in other squid species. UK Department of Trade and Industry's offshore energy Strategic Environmental Assessment program, $41 \mathrm{p}$

Stowasser G, Pierce GJ, Moffat CF, Collins MA, Forsythe JW (2006) Experimental study on the effect of diet on fatty acid and stable isotope profiles of the squid Lolliguncula brevis. J Exp Mar Biol Ecol 333:97-114

Takai N, Onaka S, Ikeda Y, Yatsu A, Kidokoro H, Sakamoto W (2000) Geographical variations in carbon and nitrogen stable isotope ratios in squid. J Mar Biol Ass UK 80:675-684

Thompson DR, Phillips RA, Stewart FM, Waldron S (2000) Low $\delta^{13}$ C signatures in pelagic seabirds: lipid ingestion as a potential source of ${ }^{13} \mathrm{C}$-depleted carbon in Procellariiformes. Mar Ecol Prog Ser 208:265-271

Thresher RE (1999) Elemental composition of otoliths as a stock delineator in fishes. Fish Res 43:165204

Tieszen LL, Boutton TW, Tesdahl KG, Slade NA (1983) Fractionation and turnover of stable carbon isotopes in animal tissues: implications for $\delta^{13} \mathrm{C}$ analysis of diet. Oecologia 57:32-37

Trull TW, Armand L (2001) Insights into Southern Ocean carbon export from the $\delta^{13} \mathrm{C}$ of particles and dissolved inorganic carbon during the SOIREE iron release experiment. Deep-Sea Res II 48:26552680

Vanderklift A, Ponsard S (2003) Sources of variation in consumer-diet $\delta^{15} \mathrm{~N}$ enrichments: a metaanalysis. Oecologia 136:169-182

Vences M, Thomas M, Bonett RM, Vieites DR (2005) Deciphering amphibian diversity through DNA barcoding: chances and challenges. Phil Trans Roy Soc B 360:1859-1868

Volkman JK, Nichols PD (1991) Applications of thin-layer chromatography-flame ionization detection to the analysis of lipids and pollutants in marine and environmental samples. J Planar Chromatography-Modern TLC 4:19-26

Wallace WG, Lopez GR (1997) Bioavailability of biologically sequestered cadmium and the implications of metal detoxification. Mar Ecol Prog Ser 147:149-157

Ward RD, Zemlak TS, Innes BH, Last PR, Hebert PDN (2005) DNA barcoding Australia's fish species. Phil Trans Roy Soc B 360:1847-1858

Xavier JC, Croxall JP, Trathan PN, Rodhouse PG (2003) Inter-annual variation in the cephalopod component of the diet of wandering albatrosses Diomedea exulans breeding at Bird Island, South Georgia. Mar Biol 142:611-622

Xavier JC, Rodhouse PG, Purves MG, Daw TM, Arata J, Pilling GM (2002) Distribution of cephalopods recorded in the diet of Patagonian toothfish (Dissostichus eleginoides) around South Georgia. Polar Biol 25:323-33 
Zauke GP, Savinov VM, Ritterhoff J, Savinova T (1999) Heavy metals in fish from the Barents Sea (summer 1994). Science Total Environ 227:161-173

Zheng X, Yang J, Lin X, Wang R (2004) Phylogenetic relationships among the decabrachia cephalopods inferred from mitochondrial DNA sequences. J Shellfish Res 23:881-886 




Fig. 1. Overview of lipid extraction and fatty acid profiling protocol. 


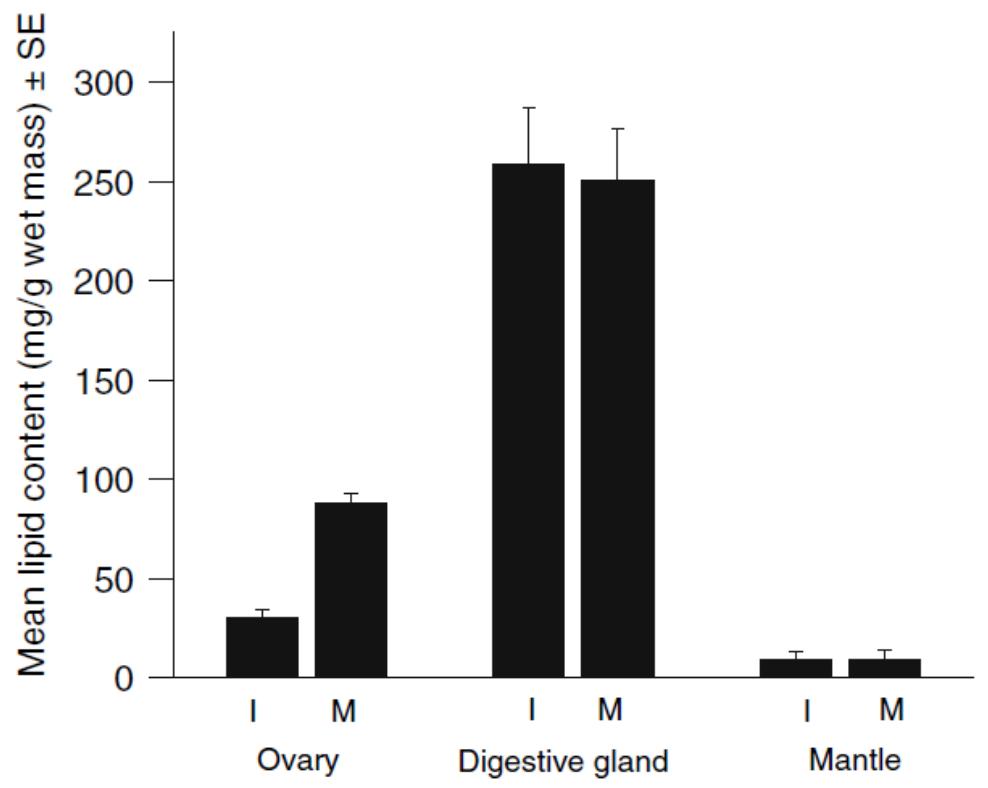

Fig. 2. Mean lipid content of ovary, digestive gland and mantle in immature (I) and mature (M) T. filippovae. 


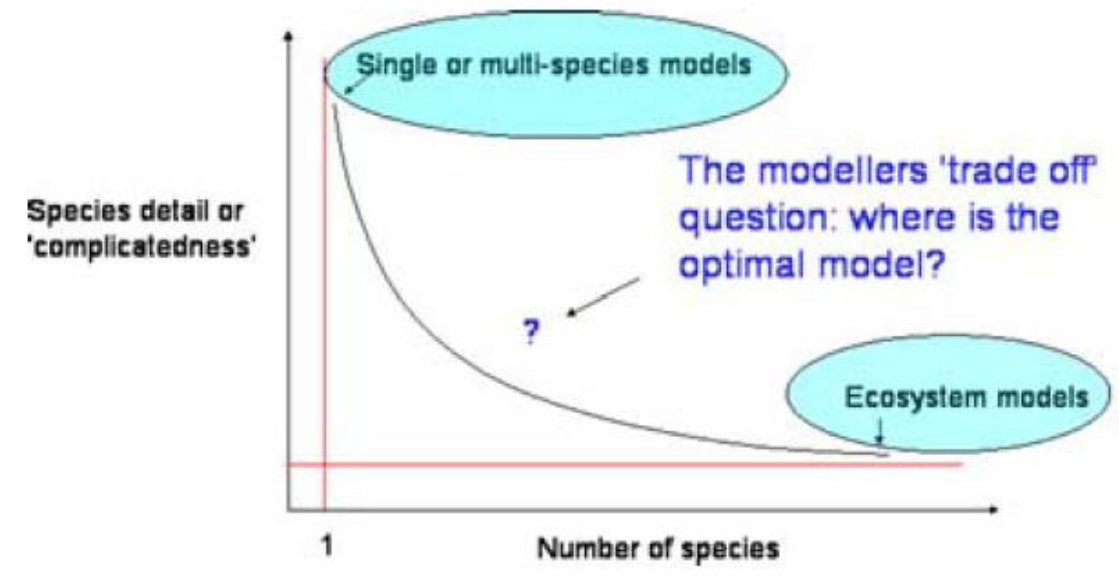

Fig. 3. Schematic diagram of ecosystem and other models showing the range of ecological model design. 


\section{(a) Atlantis -Spatial Structure}

\section{Boxes are based on bio-regionalisation}

(physical features and biological assemblages)



(b) Atlantis -Depth Structure

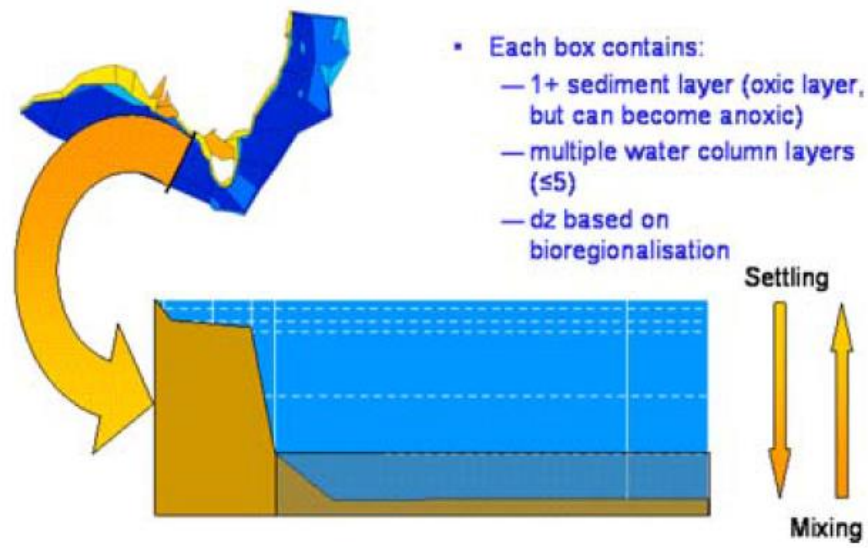

Fig. 4. Example of the Atlantis framework applied to a south-east Australia marine domain showing (a) polygonal spatial box compartments and (b) depth structure, based on bioregionalisation. 
(a)

Atlantis Example

Trophic abundances \& connections - before fishing

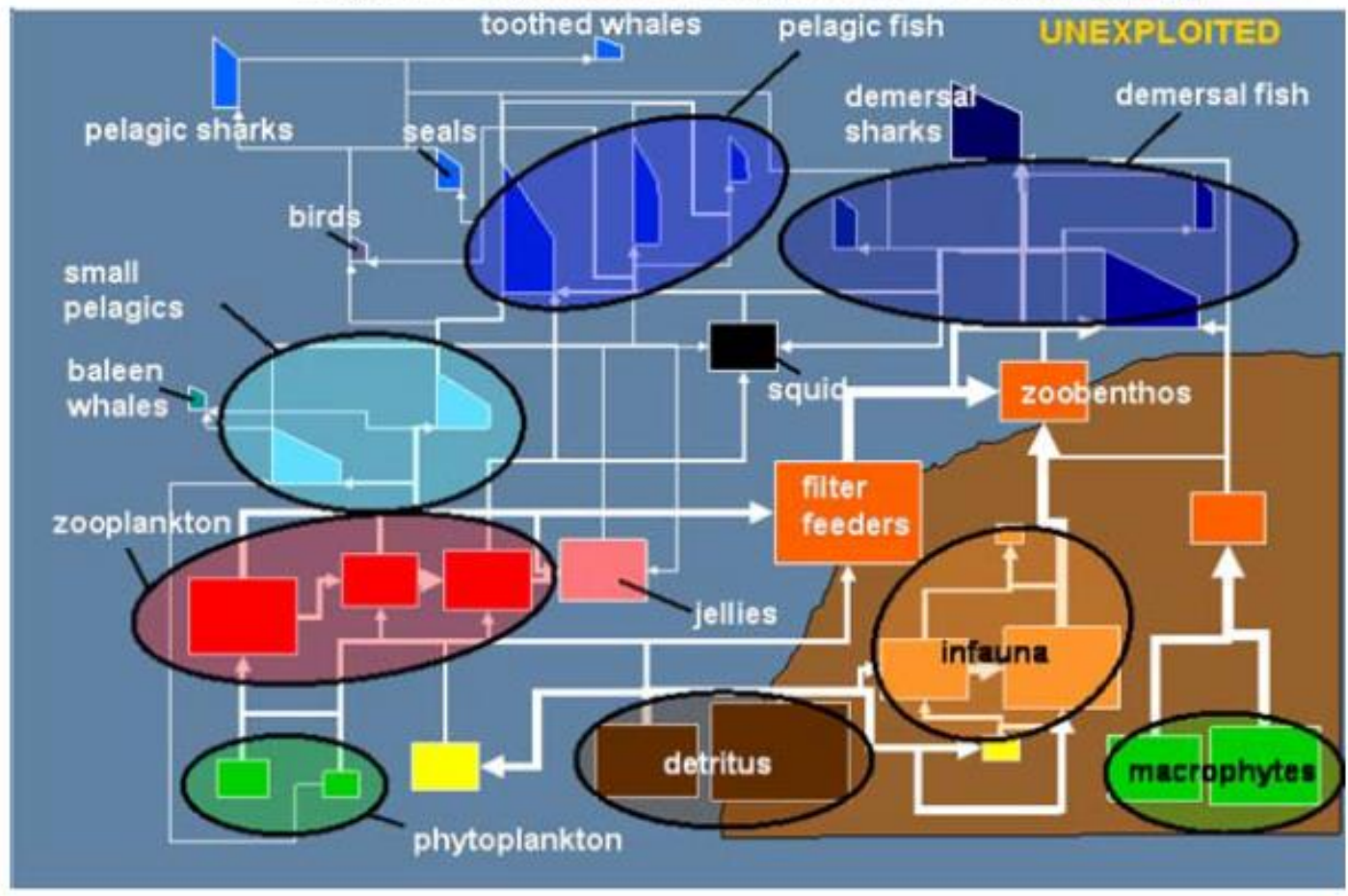

(b)

Atlantis Example

Trophic abundances \& connections - after fishing

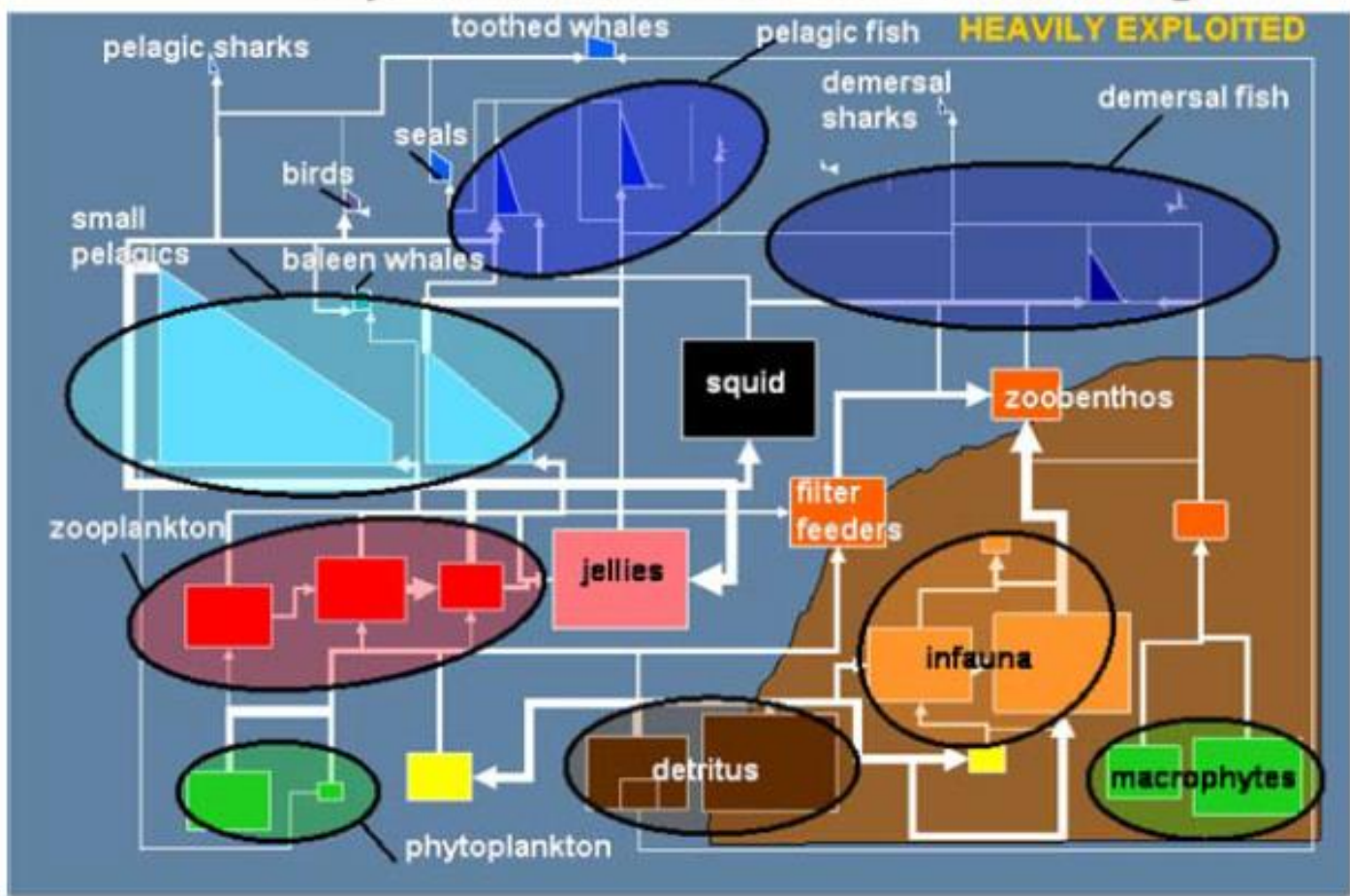

Fig. 5. Example showing how the Atlantis framework can be used to assess the potential effect of intense fishing pressure on trophic abundances and connections in the Bass Strait, by showing the food web equilibrium (a) before fishing and (b) after intense fishing effort. 
'Squidcentric' Ecosystem Model



Fig. 6. A 'squidcentric' food subweb applicable to arrow squid stocks located off of the south eastern Tasmania. The major functional groups are shown together with program code definitions. 


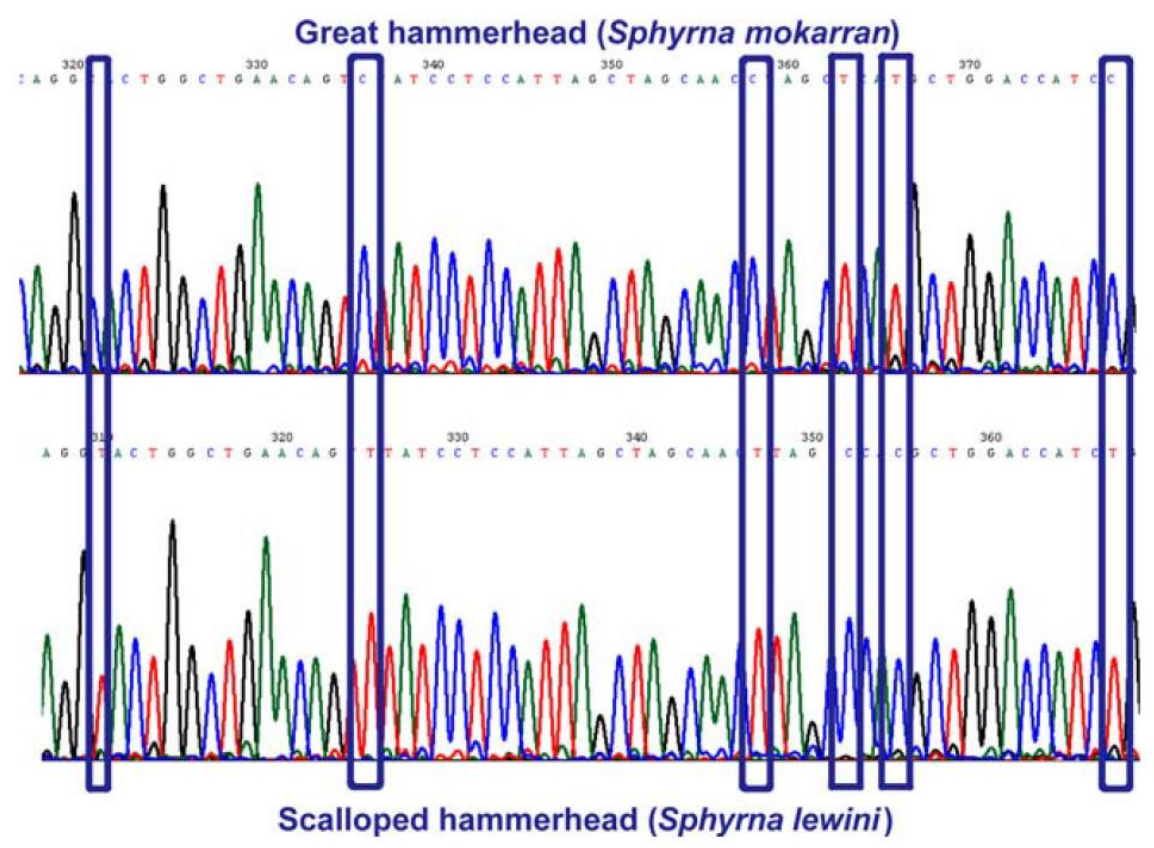

Fig. 7 Part of the COI barcode region for two species of hammerhead sharks, showing six nucleotide base changes. These scans are the outputs of automated DNA sequencers. 
(a) Lower beaks

Moroteuthis sp . B (Imber)
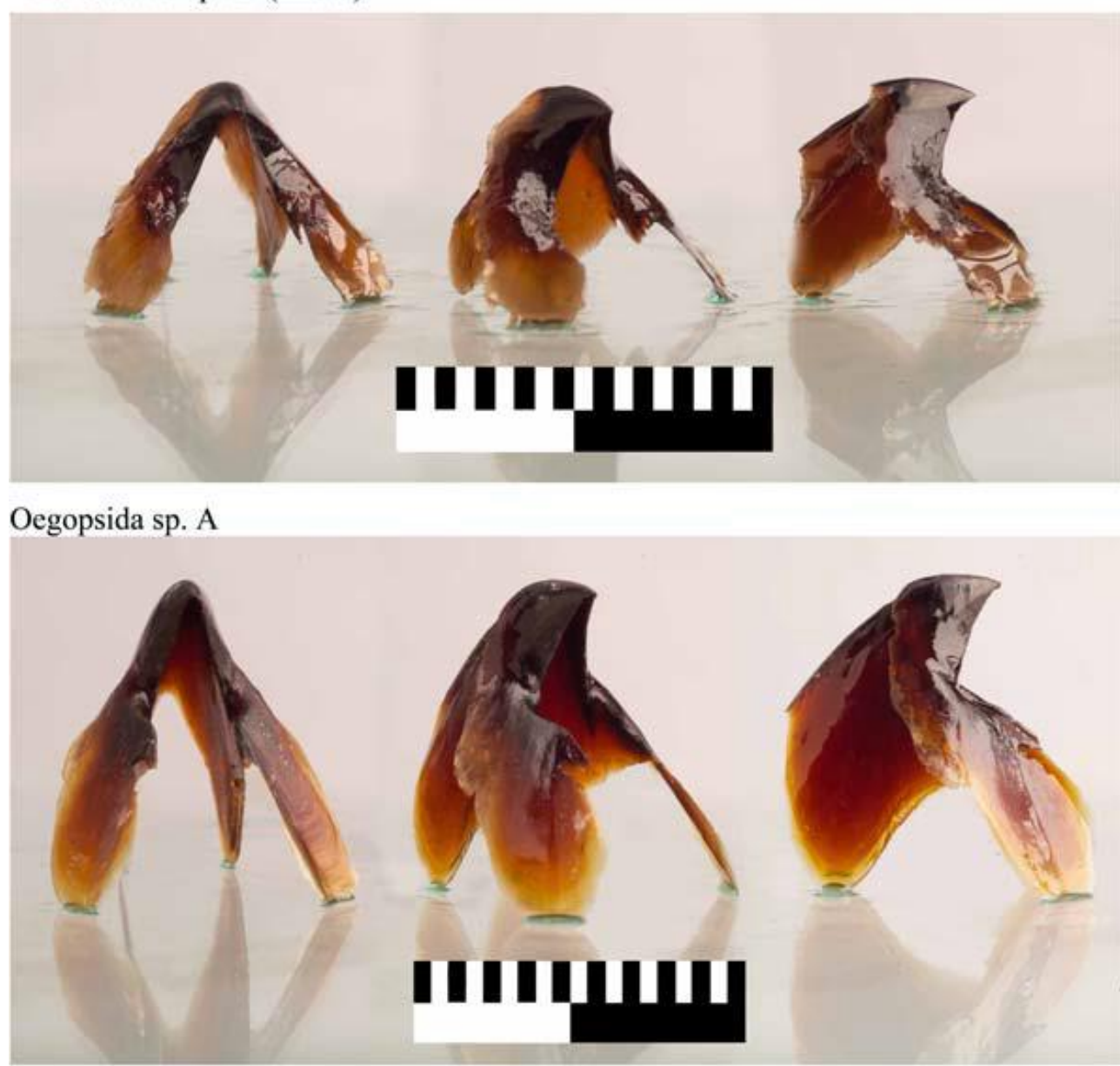

(b) Upper beaks

Moroteuthis sp . B (Imber) Oegopsida sp. A

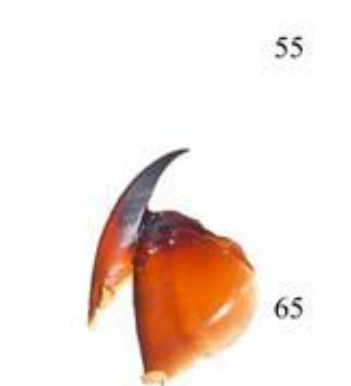

IIIUIU

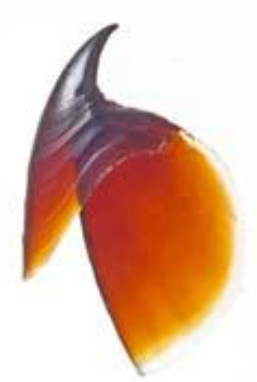

IIIUIII

Fig. 8 Lower and upper beaks of poorly known Southern Ocean Cephalopods: Moroteuthis sp. B (Imber) (lower beak from Patagonian toothfish, caught at Kerguelen, with $5.4 \mathrm{~mm}$ lower rostral length; upper beak from Patagonian toothfish, Kerguelen, with $5.0 \mathrm{~mm}$ upper rostral length) and Oegopsida sp. A (= Gonatus phoebetriae (Imber); lower beak from Patagonian toothfish, Crozet, $7.0 \mathrm{~mm}$ lower rostral length; upper beak Patagonian toothfish, Crozet, with $5.8 \mathrm{~mm}$ upper rostral length). Scale: $1 \mathrm{~cm}$. 